Klinichna khirurhiia. 2018 May;85(5):74-78.

DOI: $10.26779 / 2522-1396.2018 .05 .74$

УДК 616.33-089.843:616-056.52

\title{
Шунтування шлунка в лікуванні морбідного ожиріння
}

\author{
В. В. Москаленко \\ Національний інститут хірургії та трансплантології імені О. О. Шалімова, м. Київ

\section{Gastric shunting in treatment of morbid obesity} \\ V. V. Moskalenko \\ Shalimov National Institute of Surgery and Transplantology, Kyiv
}

\begin{abstract}
Ожиріння - це хронічне, багатофакторне, генетично обумовлене, небезпечне для життя захворювання. Спричиняє його надмірне накопичення жирової тканини в організмі. Ожиріння призводить до серйозних медичних, соціальних та економічних наслідків [1]. У 2005 р. ВООЗ запропонувала розглядати ожиріння як всесвітню пандемію неінфекційної природи, що викликає розлади здоров'я та вагомо скорочує тривалість життя. Проблема ожиріння зачіпає людей різного віку і статків. Протягом останніх трьох десятиліть жодна країна не домоглася успіху в зниженні захворюваності на ожиріння, очікується, що даний показник неухильно зростатиме, якщо не буде вжито термінових заходів щодо вирішення цієї проблеми у сфері охорони здоров'я [2].

Згідно з даними ВООЗ надлишкова вага та ожиріння є п'ятим за значущістю фактором ризику смерті у світі. Від ускладнень ожиріння щорічно помирає 3,4 млн. дорослих людей, з якими пов'язують 3,9\% втрачених років життя [3]. Крім того, надлишкова вага та ожиріння супроводжуються діабетом (44\% спостережень), ішемічною хворобою серця (23\%) та деякими видами онкологічних захворювань (7 - 41\%). Ризик цих неінфекційних захворювань зростає зі збільшенням індексу маси тіла (IMT). Більшість хворих, які мають надлишкову масу тіла та ожиріння, помирають від серцево-судинних захворювань. Ожиріння у більшості хворих асоційоване з артеріальною гіпертензією, дисліпідемією, порушеннями вуглеводного обміну та іншими станами, які є факторами ризику серцево-судинних захворювань, що спричиняють смерть [4].
\end{abstract}

В Україні 53,5\% дорослого населення старше 20 років мають надлишкову масу тіла, 21,3\% - ожиріння. Надлишкову масу тіла констатують у 50,5\% чоловіків і у 56,0\% жінок. Частка чоловіків, що хворіють на ожиріння, становить 15,9\%, жінок - 25,7\%. Прогнозована поширеність ожиріння серед населення у 2020 р. - у 32\% чоловіків і 10\% жінок. Згідно з даною прогнозною моделлю до 2030 р. хворітимуть на ожиріння 49\% чоловіків і 6\% жінок [5]. Наведені дані підтверджують актуальність питання лікування морбідного ожиріння в Україні.

Баріатричні хірургічні втручання в даний час є єдиним способом лікування, який забезпечує необхідну, стійку та сталу втрату маси тіла у пацієнтів, що хворіють на морбідне ожиріння, з подальшим зменшенням проявів супутніх захворювань, пов'язаних з ожирінням [6].

У 2013 р. у світі виконано 468609 баріатричних операцій, 3 них 95,7\% - $з$ використанням лапароскопічного доступу. Баріатрична операція, яку найчастіше застосовували у світі, це шунтування шлунка (ШШ) за Ру - 197975 (42,24\%).
Мінішунтувань шлунка (МШШ) виконано 8718 (1,86\%). У 2013 р. в Україні виконано 360 баріатричних операцій, 3 них 48,3\% - з використанням лапароскопічного доступу, ШШ - 27 (7,5\%), МШШ - 12 (3,3\%) [7].

У 1966 р. Е. Mason, хірург з Університету Айови, звернув увагу на те, що у паціентів після субтотальної резекції шлунка з приводу онкологічних захворювань значно зменшується маса тіла, та вперше запропонував застосовувати ШШ з метою лікування ожиріння. Шлунок повністю пересікали в горизонтальному напрямі, об'єм проксимального резервуара шлунка становив 100 - 150 мл (приблизно 10\% нормального об'єму шлунка) з формуванням одного позадуободового анастомоза. На відміну від методики Більрота, в запропонованому способі дистальну частину шлунка не видаляли і формували гастроентероанастомоз (ГЕА) шириною 1,2 см [8].

J. F. Alden y 1977 р. запропонував прошивати шлунок лінійним степлером без повного пересічення його стінки. Застосування апаратного механічного шва значно спростило операцію, зменшило ії тривалість і зробило значно привабливішою для хірургів [9]. W. O. Griffen і співавтори застосовували виключену за Ру петлю для попередження тяжкого жовчного рефлюксу. Об'єм резервуара шлунка - близько 100 мл, ширина ГЕА - 2 см [10].

У 1986 р. J. Н. Linner запропонував покривати ГЕА по периметру силіконовим кільцем, а пізніше - смужкою, яку викроювали з білої лінії живота, та застосовувати гастростому для декомпресії дистальної (виключеної) частини шлунка [11].

P. Salmon розробив комбінацію вертикальної гастропластики (ВГП) з ШШ і назвав цю операцію «гастропластика 3 дистальним шлунковим шунтуванням» [12]. M. A. Fobi i співавтори в 1989 р. запропонували накладати силіконове кільце на культю шлунка при ВГП (ВБГП-ШШ) [13]. У 1998 M. A. Fobi i L. Lee доповнили цю операцію транссекцією шлунка, також відому як операція Fobi (Fobi-Pouch Operation, FPO) [14].

Незалежно та майже одночасно американський хірург R. Capella запропонував методику, яка отримала назву vertical banded gastroplasty and Roux-en-Y gastric bypass (VBG-RGB) - ВБГП-ШШ за Capella. Ця методика передбачає формування вертикального бандажованого проксимального резервуара шлунка з нижньою частиною, сформованою у вигляді трапеції за допомогою лінійних степлерів. Для наступного бандажування проксимального резервуара на $2-3$ см вище місця майбутнього анастомоза використовують смужку поліпропіленової сітки довжиною 6 - 6,5 см і шириною до 2 см. Для реконструкції за Ру порожню кишку пересікають 
на відстані 30 - 40 см від підвішувальної зв'язки дванадцятипалої кишки. Дистальну частину порожньої кишки проводять позадуободово та позадушлунково для формування ГЕА ручним способом двохрядним швом. Виключену частину шлунка, дванадцятипалу кишку та проксимальну частину порожньої кишки включають за Ру на відстані 100 см від ГЕА, а у разі суперожиріння - на відстані 150 см [15].

На відміну від описаного способу, методика M. Fobi (FPO) передбачає пересікання шлунка під гострим кутом до малої кривини з прямуванням у напрямку кута Гіса. Таким чином, сформований проксимальний резервуар шлунка нагадує трикутник. Як бандаж використовують силіконову трубку довжиною 5,5 - 6 см. Порожню кишку пересікають на відстані 60 см від підвішувальної зв'язки дванадцятипалої кишки. Аліментарна петля (від ГЕА до анастомоза за Ру) має довжину також 60 см. ГЕА формують вручну двохрядним швом шириною 1,5 - 2 см. На дистальній (виключеній) частині шлунка формують гастростому, навколо якої розміщують рентгенконтрастний маркер [14].

Хоча способи ШШ за Capella і за Fobi мають окремі відмінності, описані вище, іх спільними важливими деталями є повне степлерне пересічення стінки шлунка з формуванням бандажованого проксимального резервуара шлунка об'ємом до 30 мл. Вони передбачають позадуободове та позадушлункове проведення порожньої кишки та формування ГЕА ручним способом шириною 1,5 - 2 см 3 подальшим проведенням тесту на герметичність. Важливою деталлю операції є інтерпозиція порожньої кишки поміж пересіченими частинами шлунка. У такий спосіб прикривають степлерний шов і надійно фіксують відвідну петлю, так би мовити підвішують іiі, знижучи тим самим ризик недостатності шва анастомоза [16].

Під впливом досліджень, проведених у 1979 р. N. Scopinaro, почали з'являтися повідомлення про поєднання ШШ і безпечної мальабсорбтивної операції на тонкій кишці з використанням різної довжини повної (аліментарної) і загальної (включеної) петель. Такі операції назвали longlimb gastric bypass - довгопетлеве ШШ, distal gastric bypass - дистальне ШШ та proximal gastric bypass - проксимальне ШШ. Довгопетлеве ШШ в модифікації за Torres і Оса передбачає: для «ласунів» - повну (аліментарну) петлю 244 см, загальну петлю - 152 см; для «великих їдаків» - повну (аліментарну петлю) 305 см, загальну петлю 183 см [18]; за Wood i Sapala: повну (аліментарну) петлю 200 см, загальну петлю 200 см [19]; дистальне ШШ за Wittig: повну аліментарну петлю 200 см, загальну петлю 50 см [20].

В Україні операцію ШШ за Griffen виконали в 1989 р. [21], за методом Torres i Oca - в 2001 р., з розділенням шлунка за Capella i Fobi - в 2002 p. [22, 23].

Проксимальне ШШ за Ру - це комбінація рестрикції та мальабсорбціі. Створюється невеликий резервуар шлунка, що забезпечує швидке насичення, в поєднанні з виключенням з пасажу шлунка дванадцятипалої кишки та до 200 см голодної кишки, що приводить до мальабсорбції. Звільнення дистальних гормонів кишечнику та зміни смаку також відіграють роль у механізмі дії. Технічно шлунок розділяють на верхній (проксимальний) шлунковий резервуар, об'єм якого становить 15 - 30 мл, та нижній (дистальний) шлунковий залишок. Після пересічення голодної кишки на 30 - 75 см дистальніше підвішувальної зв'язки дванадцятипалої кишки іiі дистальну частину (виключену за Ру петлю) анастомо- зують з верхнім шлунковим резервуаром. Виключену біліопанкреатичну петлю з дистальним шлунковим резервуаром включають в пасаж на 75 - 150 см дистальніше гастроєюноанастомоза [24]. Верхній шлунковий резервуар настільки зменшений, що він вміщує дуже малу кількість їжі, чим забезпечується насичення невеликими порціями. Нижній шлунковий резервуар не має контакту з їжею, проте залишається секреторно активним. Мальабсорбційний компонент ШШ досягається саме завдяки виключеній за Ру петлі, що дає можливість виключити з пасажу верхню частину тонкої кишки. Довжину виключеної за Ру петлі визначають відповідно до ІМТ пацієнта: 100 см - у пацієнтів з IMT до 48 кг $/ \mathrm{M}^{2}, 150$ см - у пацієнтів з вищим IMT. За даними останніх досліджень після ціеї операції надлишкова маса тіла зменшується на 75\% (\%EWL - \% excess weight loss $(75,15$ $\pm 18,27) \%$ протягом перших 2 років [25], а впродовж 10 років - на 51- 70\% [26, 27], хоча є повідомлення про специфічні нутритивні порушення, які потребують корекції [24, 28]. Ще одним важливим показником є частка пацієнтів 3 поверненою масою тіла (\%ВМТ), яка згідно з даними літератури варіює від 35 до 79\%.

Це пов'язане насамперед з тим, що деякі автори використовують різні показники, за яких масу тіла вважають поверненою: A. L. Freire і співавтори, C. Nicoletti і співавтори - 10\%, S. L. Odom і співавтори - 15\%, Abu Dayyeh і співавтори $-20 \%$, К. А. Соорег і співавтори - 25\% і більше [26]. Дане ускладнення зумовлює необхіднІсть повторних оперативних втручань, метою яких найчастіше є зменшення дилатованого шлункового резервуара, перекалібровка шлунково-кишкового анастомоза або переведення в іншу баріатричну процедуру - бандажоване проксимальне ШШ, дистальне ШШ, біліопанкреатичне шунтування з виключеною дванадцятипалою кишкою [29].

За даними експертних центрів частота ускладнень становить 5,2 - 20\%, серед яких недостатність швів анастомоза, кровотеча з лінії степлерного шва, стеноз чи виразка шлунково-кишкового анастомоза, венозний тромбоз, непрохідність тонкої кишки та ін. Найбільш небезпечною є недостатність швів анастомоза, яка згідно з великими серіями спостережень виникає у 0,1 - 5\% пацієнтів. Найчастіше це раннє ускладнення пов'язане з шлунково-кишковим анастомозом і є причиною смерті 0,2\% пацієнтів [27]. Високий IMT, чоловіча стать, повторна операція, старший вік та недосвідченість хірурга - фактори, які зумовлюють більш часте виникнення недостатності швів анастомоза [30, 31].

У 1996 р. A. C. Wittgrove і співавтори повідомили про перше виконання лапароскопічного ШШ. 3 доступу, через який проведено 6 троакарів, наклали 21-міліметровий циркулярний степлерний анастомоз на виключеній за Ру петлі довжиною 75 см, яку провели позадуободово позадушлунково [27]. У тому ж році H. Lonroth і співавтори запропонували з лапароскопічного доступу розділяти шлунок за допомогою лінійних степлерів та вручну формувати попередуободовий ГЕА з накладанням кліпс замість зав'язування вузлів, повідомивши про добрі результати операції та наголосивши на необхідності подальшого вдосконалення ії техніки [33].

На даний час немає стандартизованої техніки накладання ГЕА при ШШ за Ру, оскільки кожна методика має свої переваги та недоліки [34]. A. C. Wittgrove і співавтори [32] використовували циркулярний степлер для формування ГЕА, проводячи головку останнього трансорально. Щоб запобіг- 
ти ушкодженням стравоходу [35], D. J. Scott і співавтори [36] вводили головку степлера через майбутній шлунковий залишок. J. А. Теiхеira і співавтори [37] описали техніку проведення головки степлера через гастротомний отвір шлункового резервуара. ШШ з лапароскопічного доступу з формуванням ГЕА за допомогою лінійних зшиваючих апаратів вперше запропонували М. I. Korenkov і співавтори у 2003 р. [38]. В 2005 р. J. Himpens розробив безстеплерний варіант лапароскопічного ШШ за Ру з використанням лише LigaSure $\operatorname{Atlas}^{\text {TM }}$ (LSA) (Valleylab, Tyco, Boulder, CO, USA) [39]. Після пересічення за допомогою LSA стінку шлунка ушивали безперервним швом нерозсмоктуючою ниткою, завершували операцію типово. Перевагою даної методики є порівнянні вартість і отриманий баріатричний ефект [40].

Згідно з даними А. К. Madan і співавторів 43\% хірургів використовують циркулярний степлер для накладення ГЕА, 41\% віддає перевагу лінійним степлерам, а 21\% - повністю ручному ушиванню [41], незважаючи на те, що останні дослідження показали переваги використання лінійних степлерів: менша частота виникнення стриктур, інфекційних ранових ускладнень та менша тривалість операції, тоді як розміщення виключеної за Ру петлі відносно товстої кишки та шлунка залежить від уподобань хірурга [42].

R. Rutledge розробив більш просту та безпечнішу баріатричну операцію, запропонувавши МШШ (омега-шунтування, ШШ з одним анастомозом) як альтернативу ШШ за Ру: формування більш довгого шлункового резервуара (рестриктивний компонент) та унікального попередуободового гастроєюноанастомоза на 150 - 200 см дистальніше до кута Гіса (мальабсорбтивний компонент) [43]. Перша така операція виконана у 1997 р. 3 того часу R. Rutledge поділився своїм досвідом застосування цієї операції у тисяч пацієнтів [44], проте протягом тривалого часу ця методика зазнавала критики, оскільки після втручання могли розвиватися виразки анастомоза та біліарний рефлюкс, який призводив до диспластичних змін слизової оболонки шлунка та стравоходу [45].

Завдяки накопиченню досвіду застосування цієї операції в усьому світі в останні роки вона отримала широке визнання серед багатьох хірургів [46, 47]. Проте учасники Першого консенсусу з шунтування шлунка з одним анастомозом прийняли рішення вважати МШШ одним з основних хірургічних втручань та закріпили його основні технічні аспекти: довжина біліопанкреатичної петлі для всіх пацієнтів - 150 см, пересічення шлунка слід починати в горизонтальній частині малої кривини, для створення максимально довгого шлункового резервуара та, як доведено на основі експертних клінічних досліджень, дана операція прийнятна для молодих пацієнтів та вегетаріанців, не призводить до неогенезу стравоходу та шлунка, через що може застосовуватись як при помірно вираженій гастроезофагеальній рефлюксній хворобі, так і при великих грижах стравохідного отвору діафрагми [48].

Після МШШ у пацієнтів більш виражено зменшуються маса тіла (на 70 - 80\% за перші два роки), прояви супутньої патології, ніж після ШШ за Ру, сама ж операція є менш складною та менш інвазивною, що особливо важливо для пацієнтів 3 мультипатологією або суперожирінням [49, 50]. Також слід відзначити надшвидке вирішення проблеми цукрового діабету 2 типу, оскільки більшість пацієнтів припиняє інсулінотерапію через декілька днів після операції [51].
Враховуючи добрі результати та безпечність бандажованого ШШ за Py, L. Sheikh і співавтори впровадили бандажоване MШШ (SR-MGBP). Особливістю методики є те, що в дистальній третині сформованого шлункового резервуара на 2 см вище ГЕА накладають силіконове кільце шириною 6,5 7 см, яке фіксують нерозсмоктуючим шовним матеріалом. Впродовж 11-річного спостереження не виявлено переваг перед оригінальною методикою у зменшенні надлишкової маси тіла чи проявів супутньої патології, проте зафіксовані побічні ефекти, асоційовані з бандажуванням, які призвели до дебандажування у 3,6\% хворих [52].

Вперше в Україні ШШ за Ру з лапароскопічного доступу виконано в 2012 р. [53], а МШШ - в клініці Національного інституту хірургії та трансплантології імені О. О. Шалімова в 2013 р. [54].

На жаль, як і всі баріатричні втручання, операції ШШ мають небажані побічні ефекти. До ранніх відносять зневоднення та демпінг-синдром. Зневоднення є загальною проблемою, і пацієнти повинні звикнути до вживання на постійній основі 1,5 - 2 л рідини на день. Майже 85\% пацієнтів після ШШ відчувають прояви «демпінг-синдрому», але хірургічне лікування таким пацієнтам не рекомендується і застосовується лише тоді, коли іншого виходу немає [28]. Пацієнти $з$ демпінг-синдромом мусять проходити повторне навчання задля відмови від вживання певних продуктів харчування. Маючи малий об'єм шлункового резервуара, вони повинні споживати невелику кількость їжі, їсти до 6 разів на день і уникати вуглеводного навантаження, яке може призвести до демпінг-синдрому [4]. Хоча маса парієтальних клітин невелика, виникнення виразки анастомоза діагностують у 2\% хворих після операцій ШШ впродовж першого року, в строки до 5 років частота цього ускладнення становить 0,5\% [55]. Такі ускладнення частіше виникають у курців та пацієнтів, які $є$ H. pylori - позитивними. Щодо виразок анастомоза добрі результати має лікування інгібіторами протонної помпи, але при резистентності виникає необхідність у ревізійній хірургії. У разі підвищення рівня сироваткового гастрину може виникнути потреба видалення виключеного шлункового залишка, але лише за умови, що між проксимальним та дистальним шлунковими залишками немає нориці [4].

Нутритивна недостатність та гіповітаміноз є пізніми ускладненнями. Найчастішою причиною таких станів $є$ порушення пацієнтом рекомендацій. Дотримання дієти та вживання полівітамінних добавок у підтримуючій дозі зазвичай достатньо для попередження розвитку ускладнень [56].

Внутрішні грижі можуть розвиватися після лапароскопічного ШШ через створення невеликих дефектів у вісцеральній очеревині (у брижі поперечної ободової кишки або позаду виключеної за Ру петлі) та утворення менше злук, які б могли фіксувати петлю тонкої кишки та запобігти розвитку грижі [4]. Крім того, пацієнти, які мають більш виражене зменшення маси тіла після лапароскопічного ШШ за Ру, більш схильні до виникнення внутрішньої грижі через втрату вісцеральної жирової клітковини, наявність якої також знижує ймовірність утворення грижі. Частота виникнення внутрішніх гриж після ШШ за Ру становить 0,4 - 5,5\%, тоді як є повідомлення про поодинокі спостереження утворення гриж після МШШ у великих серіях спостережень [57]. Питання рубцевих гриж стрімко втрачає свою актуальність після впровадження лапароскопічної хірургії [4]. 


\section{References}

1. WHO. Global status report on noncommunicable diseases. 2014 Geneva, Switzerland: World Health Organization. http://apps.who.int/iris/bitstre am/10665/148114/1/9789241564854_eng.pdf?ua=1.

2. Ng M, Fleming T, Robinson M, Thomson B, Graetz N, Margono C, et al. Global, regional, and national prevalence of overweight and obesity in children and adults during 1980-2013: a systematic analysis for the Global Burden of Disease Study 2013. Lancet. 2014 Aug 30;384(9945):766-81. doi: 10.1016/S0140-6736(14)60460-8.

3. Murray CJ, Vos T, Lozano R, Naghavi M, Flaxman AD, Michaud C, et al. Disability-adjusted life years (DALYs) for 291diseases and injuries in 21 regions? 1990-2010: a systematic analysis for Global Burden of Disease Study 2010. Lancet. 2012 Dec 15;380(9859):2197-223.

doi: 10.1016/S0140-6736(12)61689-4.

4. Weledji EP. Overview of gastric bypass surgery. Int J Surg Open. 2016;5:119. doi: 10.1016/j.ijso.2016.09.004.

5. Report on modelling adulthood obesity across the WHO European Region, prepared by consultants (led by Marsh T. and colleagues) for the WHO Regional Office for Europe in 2013. http://www.euro.who.int/ data/assets/ pdf_file/0019/243334/Ukraine-WHO-Country-Profile.pdf?ua=1.

6. Sjöström L, Peltonen M, Jacobson P, Sjöström CD, Karason K, Wedel H, et al. Bariatric surgery and long-term cardiovascular events. JAMA. 2012 Jan 4;307(1):56-65. doi: 10.1001/jama.2011.1914.

7. Angrisani L, Santonicola A, Iovino P, Formisano G, Buchwald H, Scopinaro N. Obes Surg. 2015 Oct;25(10):1822-32. doi: 10.1007/s11695-015-1657-z.

8. Mason EE, Ito C. Gastric bypass in obesity. Surg Clin North Am. 1967 Dec;47(6):1345-51. https://www.ncbi.nlm.nih.gov/pubmed/6073761.

9. Alden JF. Gastric and jejuno-ileal bypass: a comparison in treatment of morbid obesity. Arch Surg. 1977 Jul;112(7):799-806. https://www.ncbi.nlm. nih.gov/pubmed/880023.

10. Griffen WO, Young VL, Stevenson CC. A prospective comparison of gastric and jejunoileal bypass procedures for morbid obesity. Surg Obes Relat Dis. 2005 Mar-Apr;1(2):163-72; discussion 173-4. doi: 10.1016/j.soard.2005.02.015.

11. Linner JH, Drew RL. New modification of Roux-en-Y gastric bypass procedure. Clin Nutr. 1986;5:33-7.

12. Salmon PA. Gastroplasty with distal gastric bypass: a new and more successful weight loss operation for morbidly obese. Can JSurg. 1988;31:111-4.

13. Fobi MA, Lee H, Flemming AW. The surgical technique of the banded gastric bypass. J Obes \& Weight Regulation. 1989;8:99-102.

14. Fobi MA, Lee H, Holness R, Cabinda D. Gastric bypass operation for obesity. World J Surg. 1998 Sep;22(9):925-935. https://www.ncbi.nlm.nih.gov/ pubmed/9717418.

15. Capella RF, Capella JF. Reducing early technical complications in gastric bypasssurgery. Obes Surg. 1997 Apr;7(2):149-56; discussion 157. doi:10.1381/096089297765556060.

16. Tyvonchuk OS. Rol ta mistse shuntuvannia ta bandazhuvannia shlunku v suchasnii bariatrychnii khirurhii. XI/XII Ukr. med. chasopys, 2007;6(62):6375. http://www.umj.com.ua/wp/wp-content/uploads/archive/62/pdf/58_ rus.pdf.

17. Scopinaro N, Gianetta E, Civalleri D, et al. Biliopancreatic bypass for obesity: II. Initial experience in man. Br J Surg. 1979;66:618-20.

18. Torres JC, Oca CF, Garrison RN. Gastric bypass Roux-en-Y gastrojejunostomy from the lesser curvature. South Med J. 1983;76:1217-20.

19. Wood MF, Sapala JA, Sapala MA, Schuhknecht MP, Flake TM. Micropouch gastric bypass: indications for gastrostomy tube placement in the bypassed stomach. Obes Surg. 2000 Oct;10(5):413-9. https://www.ncbi.nlm. nih.gov/pubmed/11054245.

20. Wittig JH. Biliopancreatic bypass: a revision for other gastricrestrictive procedures. In: Proceedings, Fourth Annual Symposium Surgical Treatment of Obesity, Anaheim, CA, March 5-8, 1986.

21. Saenko VF, Lavrik AS, Stecenko AP. Problemy hirurgicheskogo lechenija ozhirenija. Zhurnal AMN Ukrainy. 1999;5(4):694-9 [In Russian].

22. Lavrik AS, Saenko VF, Tyvonchuk AS, Andreeshhev SA, Furmanenko ED. Shuntirovanie zheludka v hirurgicheskom lechenii patologicheskogo ozhirenija. Klinichna khirurhiia, 2003;(3):14-7 [In Russian].

23. Tyvonchuk AS. Vozmozhnosti hirurgicheskoj korrekcii morbidnogo ozhirenija shuntirovaniem zheludka. Aktualni pytannia medychnoi nauky ta praktyky. Zbirnyk naukovykh prats. Zaporizhzhia: Dyke Pole; 2004;67(1):3259. [In Russian].

24. Marmuse JP, Parenti LR. Gastric bypass. Principles, complications, and results. J Visc Surg. 2010 Oct;147(5 Suppl):31-7. doi:10.1016/j.jviscsurg.2010.08.014
25. Monaco-Ferreira DV, Leandro-Merhi VA. Weight Regain 10 Years After Roux-en-Y Gastric Bypass. Obes Surg. 2017 May;27(5):1137-44. doi: 10.1007/s11695-016-2426-3.

26. Higa K, Ho T, Tercero F, Yunus T, Boone KB. Laparoscopic Rouxen-Y gastric bypass: 10-year follow-up. Surg Obes Relat Dis. 2011 JulAug;7(4):516-25. doi: 10.1016/j.soard.2010.10.019.

27. Buchwald H, Buchwald JN, McGlennon TW. Systematic review and meta-analysis of medium-term outcomes after banded Roux-en-Y gastric bypass. Obes Surg. 2014 Sep;24(9):1536-51. doi: 10.1007/s11695014-1311-1.

28. Neff KJ, Olbers T, le Roux CW. Roux Bariatric surgery: the challenges with candidate selection, individualizing treatment and clinical outcomes. BMC Med. 2013 Jan 10;11:8. doi: 10.1186/1741-7015-11-8.

29. Himpens J1, Coromina L, Verbrugghe A, Cadière GB. Outcomes of Revisional Procedures for Insufficient Weight Loss or Weight Regain After Roux-En-Y Gastric Bypass. Obes Surg. 2012 Nov;22(11):1746-54. doi: 10.1007/s11695-012-0728-7.

30. Smith MD1, Patterson E, Wahed AS, Belle SH, Berk PD, Courcoulas AP, et al. Thirty-day mortality after bariatric surgery: independently adjudicated causes of death in the longitudinal assessment of bariatric surgery. Obes Surg. 2011 Nov;21(11):1687-92. doi: 10.1007/s11695-011-0497-8.

31. Maciejewski ML1, Livingston EH, Smith VA, Kavee AL, Kahwati LC, Henderson WG, Arterburn DE. Survival among high-risk patients after bariatric surgery. JAMA. 2011 Jun 15;305(23):2419-26. doi: 10.1001/jama.2011.817.

32. Wittgrove AC, Clark GW, Tremblay LJ. Laparoscopic gastric bypass, Rouxen-Y: preliminary report of five cases. Obes Surg. 1994 Nov;4(4):353-7. doi: $10.1381 / 096089294765558331$.

33. Lönroth H, Dalenbäck J, Haglind E, Lundell L. Laparoscopic gastric bypass. Another option in bariatric surgery. Surg Endosc. 1996;10:636-8. https://www.ncbi.nlm.nih.gov/pubmed/8662402.

34. Giordano S1, Salminen P, Biancari F, Victorzon M. Linear stapler technique may be safer than circular in gastrojejunal anastomosis for laparoscopic Roux-en-Y gastric bypass: A Meta-analysis of Comparative Studies. Obes Surg. 2011 Dec;21(12):1958-64. doi: 10.1007/s11695-011-0520-0.

35 Abdel-Galil E, Sabry AA. Laparoscopic Roux-en-Y gastric bypass - evaluation of three different techniques. Obes Surg. 2002 Oct;12(5):639-42. https://www.ncbi.nlm.nih.gov/pubmed/12448384.

36. Scott DJ, Provost DA, Jones DB. Laparoscopic Roux-en-Y gastric bypass: transoral or transgastric anvil placement? Obes Surg. 2000 Aug;10(4):3615. doi: 10.1381/096089200321629139.

37. Teixeira JA1, Borao FJ, Thomas TA, Cerabona T, Artuso D. An alternative technique for creating the gastrojejunostomy in laparoscopic Roux-en-Y gastric bypass: experience with 28 consecutive patients. Obes Surg. 2000 Jun;10(3):240-4. doi: 10.1381/096089200321643520.

38. Korenkov M1, Goh P, Yücel N, Troidl H. Laparoscopic gastric bypass for morbid obesity with linear gastroenterostomy. Obes Surg. 2003 Jun;13(3):360-3. doi: 10.1381/096089203765887660.

39. Himpens J, Leman G, Sonneville T. Laparoscopic Roux-en-Y gastric bypass performed without staples. Surg Endosc. 2005 Jul;19(7):1003. doi: 10.1007/s00464-004-2142-2

40. Ettinger JE1, Ramos AC, Azaro E, Galvão-Neto MP, Mello CA, Galvão MS, et al. Staplerless laparoscopic gastric bypass: a new option in bariatric surgery. Obes Surg. 2006 May;16(5):638-45. doi: $10.1381 / 096089206776944896$.

41. Madan AK, Harper JL, Tichansky DS. Techniques of laparoscopic gastric bypass: on-line survey of American society for bariatric surgery practicing surgeons. Surg Obes Relat Dis. 2008 Mar-Apr;4(2):166-72; discussion 172-3. doi: 10.1016/j.soard.2007.08.006.

42. Sundbom M. Laparoscopic revolution in bariatric surgery. World J Gastroenterol. 2014 Nov 7;20(41):15135-43. doi: 10.3748/wjg.v20.i41.15135.

43. Rutledge R. The mini-gastric bypass: experience with the first 1,274 cases Obes Surg. 2001 Jun;11(3):276-80. doi: 10.1381/096089201321336584.

44. Rutledge R, Walsh TR. Continued excellent results with the mini-gastric bypass: six-year study in 2,410 patients. Obes Surg. 2005 Oct;15(9):1304 8. doi: 10.1381/096089205774512663.

45. Mahawar KK, Carr WRJ, Balupuri S, Small PK. Controversy surrounding 'mini' gastric bypass. Obes Surg. 2014;24(2):324-33. doi: 10.1007/ s11695-13-1090-0.

46. Bruzzi M, Rau C, Voron T, Guenzi M, Berger A, Chevallier JM. Single anastomosis or mini-gastric bypass: long-term results and quality of life after a 5-year follow-up. Surg Obes Relat Dis. 2015 Mar-Apr;11(2):3216. doi: 10.1016/j.soard.2014.09.004. 
47. Georgiadou D, Sergentanis TN, Nixon A, Diamantis T, Tsigris C, Psaltopoulou T. Efficacy and safety of laparoscopic mini gastric bypass. A systematic review. Surg Obes Relat Dis. 2014 Sep-Oct;10(5):984-91. doi: 10.1016/j. soard.2014.02.009.

48. Mahawar KK, Himpens J, Shikora SA, Chevallier JM, Lakdawala M, De Luca M. The first consensus statement on one anastomosis. mini gastric bypass (oagb/mgb) using a modified delphi approach. Obes Surg. 2017 Dec 14. doi: 10.1007/s11695-017-3070-2.

49. Lee WJ1, Ser KH, Lee YC, Tsou JJ, Chen SC, Chen JC. Laparoscopic Roux-en-Y vs. mini-gastric bypass for the treatment of morbid obesity: a 10-year experience. Obes Surg. 2012 Dec;22(12):1827-34. doi: 10.1007/ s11695-012-0726-9.

50. Lee WJ, Lin YH. Single-anastomosis gastric bypass (SAGB): appraisal of clinical evidence. Obes Surg. 2014 Oct;24(10):1749-56. doi: 10.1007/ s11695-014-1369-9.

51. Disse E, Pasquer A, Espalieu P, Poncet G, Gouillat C, Robert M. Greater weight loss with the omega loop bypass compared to the Roux-en-Y gastric bypass: a comparative study. Obes Surg. 2014 Jun;24(6):841-6. doi: 10.1007/s11695-014-1180-7.

52. Sheikh L, Pearless L, Booth M. Laparoscopic silastic ring mini-gastric bypass (SR-MGBP): up to 11-year results from a single centre. Obes Surg. 2017;27:2229-34. doi: 10.1007/s11695-017-2659-9.
53. Ioffe OYu, Tsiura YuP, Stetsenko OP, Tarasiuk TV, Kryvopustov M S. Laparoskopichne shuntuvannia shlunka yak operatsiia vyboru u khvorykh pry morbidnomu ozhyrinni ta suputnomu metabolichnomu syndromi. Klinichna khirurhiia. 2013;(11):17-20. [In Ukrainian].

54. Tyvonchuk AS, Lavrik AS. Puti uluchshenija otdalennyh rezul'tatov shuntirovanija zheludka. Annaly Hirurgii. Prilozhenie. Hirurgicheskoe lechenie ozhirenija i metabolicheskih narushenij. Materialy Sed'mogo rossijskogo simpoziuma s mezhdunarodnym uchastiem. Ekaterinburg. 2013 4-6 ijulja p 47-8. [In Russian].

55. Csendes A, Torres J, Burgos AM. Late marginal ulcers after gastric bypass formorbid obesity. Clinical and endoscopic findings and response to treatment. Obes Surg. 2011 Sep;21(9):1319-22. doi: 10.1007/s11695-0110429-7.

56. Homan J, Schijns W, Aarts EO, Janssen IMC, Berends FJ, de Boer H. Treatment of vitamin and mineral deficiencies after biliopancreatic diversion with or without duodenal switch: a major challenge. Obes Surg. 2018 Jan;28(1):234 41. doi: 10.1007/s11695-017-2841-0.

57. Jammu GS, Sharma R. A 7-year clinical audit of 1107 cases comparing sleeve gastrectomy, Roux-en-Y gastric bypass, and mini-gastric bypass, to determine an effective and safe bariatric and metabolic procedure. Obes Surg. 2016 May;26(5):926-32. doi: 10.1007/s11695-015-1869-2. 